Revta brasil. Bot., São Paulo, V.21, n.1, p.65-72, abr. 1998

\title{
Response of Dalbergia miscolobium Benth. seedlings, a cerrado tree species, to mineral nutrient supply
}

\author{
REGINA M. SASSAKI ${ }^{1}$ and G.M. FELIPPE ${ }^{1}$
}

(recebido em 16/10/96; aceito em 10/06/97)

\begin{abstract}
Response of Dalbergia miscolobium Benth. seedlings, a cerrado tree species, to a mineral nutrient supply). The soil under the Brazilian cerrado vegetation is very poor in nutrients. The aim of this study was to investigate the effect of the addition of a nutrient solution in the early growth of $D$. miscolobium, a typical cerrado tree species, cultivated in cerrado soil. Seeds were germinated in Petri dishes and seven-day old seedlings were transfered to pots containing cerrado soil. These were supplied once a week with a normal, $1 / 2$ or $1 / 10$ strength nutrient solution. Four growth analysis were done over a period of 145 days from seed imbibition, in terms of dry mass, leaf area and carbohydrate and nitrogen contents. Other derived parameters were also analysed. The addition of a nutrient solution promoted early growth with a preferential separation of dry matter towards the tops; in the control seedlings (no nutrient addition) more dry matter accumulated in the root system. This suggests a preferential investment in root growth in poor soils such as the cerrado ones. Reliable evidence of this is given by the level of carbohydrate and protein which was higher in the roots than in the tops of plants growing in cerrado soil without the addition of nutrients.
\end{abstract}

RESUMO - (Resposta das plântulas de Dalbergia miscolobium Benth., uma espécie arbórea de cerrado, à adição de nutrientes minerais). O solo sob vegetação do cerrado brasileiro é muito pobre em nutrientes. O objetivo deste trabalho foi o estudo do efeito da adição de solução nutritiva sobre o crescimento inicial de D. miscolobium, uma espécie arbórea nativa do cerrado, cultivada em solo de cerrado. As sementes foram germinadas em placas de Petri e plântulas com sete dias foram transferidas para recipientes contendo solo de cerrado. Estas foram supridas, uma vez por semana, com solução nutritiva normal, diluída duas vezes ou diluída 10 vezes. Quatro análises de crescimento foram feitas por um período de 145 dias desde o início da embebição das sementes, em termos de massa de matéria seca, área foliar e conteúdo de carboidratos e de nitrogênio. Outros parâmetros derivados também foram avaliados. A adição da solução nutritiva promoveu o crescimento inicial com partição preferencial de matéria seca para a parte aérea; nas plântulas controle (sem adição de nutrientes) mais matéria seca foi acumulada no sistema radicular. Isto sugere um investimento preferencial no crescimento da raiz em solos mais pobres como os de cerrado.Uma boa evidência sobre isso é dada pelo nível de carboidratos e proteínas, o qual foi maior nas raízes do que nas partes aéreas em plantas crescendo em solo de cerrado sem solução nutritiva.

Key words - Dalbergia miscolobium, carbohydrate content, nitrogen content, early growth, nutrient solution

\section{Introduction}

It is well-known that in nutrient deficient soils there is higher allocation of matter to the roots than to the tops (Mooney 1972, Chapin 1980) leading to a high root/top ratio (Wilson 1988). Increased nutrient level causes the root/top ratio to decrease but the growth patterns are different from species to species (Vaitkus et al. 1993).

The fertility of cerrado soils is very low (Alvim et al. 1968). Arens (1958a, b, 1963) suggested that the low nutrient levels of cerrado soils, mainly the levels of phosphorus, nitrogen and sulphur, lead to a low production of proteins, and to the storage of carbohydrates produced by photosynthesis, the accumulation of carbohydrates causing scleromorphism and the lack of protein a reduction of

1. Seção de Fisiologia e Bioquímica de Plantas, Instituto de Botânica, Caixa Postal 4005, 01061-970 São Paulo, SP, Brazil. Research Fellow, CNPq. growth. Paulilo \& Felippe (1994) showed an increased sugar content of the cotyledons of Qualea grandiflora growing in cerrado soil without nutrient addition which meant that the products of photosynthesis were not readily distributed within the plant; at the same time they showed a decrease in protein level, and a deficiency of nitrogen, which was responsible for the slow growth of the seedling.

To understand the effect of nutritional conditions of the substratum upon the initial growth of some cerrado species, studies were carried out in which a nutrient solution was added to cerrado soil. However, the addition of a nutrient solution did not promote growth in seedlings of another cerrado tree species, Qualea cordata and when higher strength nutrient solution was used, a reduction of growth was observed (Godoy-Aveiro \& Felippe 1992). Similar results were obtained with seedlings of Qualea grandiflora grown in washed sand under controlled conditions (light and temperature regimes) for a long period (213 days); the addition of nutrient solution 
which was diluted 10 times, but in which the level of phosphorus was higher than that found in cerrado soils, a toxic effect was observed upon the seedlings (Felippe \& Dale 1990). However, when the seedlings of the same species were grown in cerrado soil for a shorter period of time ( 80 days) the addition of nutrients increased the root dry mass by $80 \%$ (Paulilo \& Felippe 1995).

Sassaki \& Felippe (1992a) showed that the cotyledons of Dalbergia miscolobium remain on the seedlings for a very long period of time (about 75 days) and if they are removed early (4, 7 and 10 days from the beginning of imbibition) the effect upon growth is much more dramatic than with later removal. The addition of nutrients did not substitute for the early removal of cotyledons (experiments lasting 30 days), showing that, at this stage, the seedlings are fully dependent on the reserves of their cotyledons. However, after the reserves are used up, the seedlings will depend for growth on the nutrients from the cerrado soil. In this paper we report the effect of the addition of nutrient solution upon growth of D. miscolobium in experiments lasting beyond the period in which the cotyledons are present.

\section{Material and methods}

Seeds of Dalbergia miscolobium Benth. were germinated in Petri dishes according to Sassaki \& Felippe (1992b): seeds were distributed over two-folded wet filter paper and the Petri dishes were mantained at $25^{\circ} \mathrm{C}$ under continuous white light. Sevenday old seedlings were transferred to pots $(13 \mathrm{~cm}$ diameter and $30 \mathrm{~cm}$ deep) containing cerrado soil (table 1). The pots were kept in greenhouse (semi-controlled conditions) in Campinas ( $\left.22^{\circ} 54^{\prime} \mathrm{S}\right)$, São Paulo state, Brazil, from September $25^{\text {th }}, 1993$ to February $10^{\text {th }}, 1994$, during spring and summer. The seedlings were supplied once a week with normal, 1/2 and 1/10 strength nutrient solution based on that of Hoagland \& Arnon (1938); the control ones received only distilled water when needed. Distilled water was also added to the soil in pots treated with nutrient solution when needed but not two days before and two days after nutrient solution application, to avoid dilution of the nutrient solution.
After 24 days from transferring (31 days from seed imbibition) seedling to the soil, the first growth analysis was made. Three more analysis were made until 145 days after seed imbibition had started.

Dry mass of the diffcrent seedling parts was measured after keeping them for $48 \mathrm{~h}$ at $80^{\circ} \mathrm{C}$ with forced air. The root/top ratio,in terms of dry mass was estimated using these data. Leaf area was determined using a leaf arca and analysis programme from Skye Instruments. Growth analysis parameters as the relative growth rate $(\overline{\mathrm{R}})$, net assimilation rate $(\overline{\mathrm{E}})$, leaf arca ratio (LAR), leaf weight ratio (LWR) and specific leaf area (SLA) were analysed according to Hunt (1982).

For the extraction of carbohydrates the plant parts (roots and tops) were firstly subjected to extraction in $\mathrm{MCW}$ (methanol:chloroform:water - 12:5:3: v/v/v) followed by extraction in 10\% ethanol, according to Shannon (1968). The resulting residue was then treated with perchloric acid to extract starch (McCready et al. 1950). Quantitative determination of starch was done by the anthrone reagent method using glucose as standard and applying the correction factor 0.9 to convert glucose content to starch. Total nitrogen was analysed by the micro-Kjeidahl method according to Umbreit et al. (1957). Total protein was estimated applying the factor 6.25 to the nitrogen content values obtained.

Analysis of variance (Tukey) was used to compare the data(Snedecor 1962). For the derived data used in the growth analysis $(\overline{\mathrm{R}}, \overline{\mathrm{E}})$, the statistical analysis was done on the variation observed in the second harvest only, as the seedlings were destroyed afler each harvest.

\section{Results}

The effect of different strengths of nutrient solution was seen in one experiment that was carried out during 145 days. Between 108 and 145 days (last harvest) of the experiment the seedlings treated with normal strength Hoagland solution presented yellow leaves or all the leaves were abscinded; thus no measurements were done in the seedlings of this treatment on day 145 .

There was no effect of addition of nutrients in the dry mass of the seedlings on day 31 (figure 1). No statistical effect of addition of nutrients could beseen in the case of the roots on day 145 . However, the different solutions affected dry mass of stem and

Table 1. Chemical analysis of the soil from cerrado used for growing seedlings of D. miscolobium. Analysis provided by Seção de Fertilidade do Solo e Nutrição de Plantas of Instituto Agronômico de Campinas, Brazil.

\begin{tabular}{lccccccccc}
\hline $\begin{array}{l}\mathrm{P}_{\text {resin }} \\
\mu \mathrm{g} / \mathrm{cm}^{3}\end{array}$ & $\begin{array}{c}\text { O.M. } \\
\%\end{array}$ & $\begin{array}{c}\text { A.I. } \\
\mathrm{pH} \mathrm{CaCl}\end{array}$ & $\mathrm{K}^{+}$ & $\mathrm{Ca}^{2+}$ & $\mathrm{Mg}^{2+}$ & $\begin{array}{c}\mathrm{H}^{+}+\mathrm{Al}^{3+} \\
\mathrm{meq} / 100 \mathrm{~cm}^{3}\end{array}$ & $\mathrm{SB}$ & $\mathrm{CEC}$ & $\begin{array}{c}\mathrm{V} \\
\%\end{array}$ \\
\hline 2 & 0.7 & 4.1 & 0.001 & 0.1 & 0.1 & 2.3 & 0.2 & 2.5 & 8 \\
\hline
\end{tabular}

O.M. $=$ organic matter; A.I. $=$ acidity index $\mathrm{H}^{+}+\mathrm{Al}^{3+}=$ potential acidity; $\mathrm{SB}=$ sum of bases $; \mathrm{CEC}=$ cation exchange capacity: $\mathrm{SB}+$ $\left(\mathrm{H}^{+}+\mathrm{Al}^{3+}\right) ; \mathrm{V}=$ saturation of bases: $(\mathrm{SB} / \mathrm{CEC}) \times 100$. 
leaves (and thus tops): the $1 / 2$ strength solution promoted growth, followed by $1 / 10$ strength solution and then water until day 145. On day 108 the promotion could be seen also with the normal strength solution. Increasing the strength of the solution decreased the root/top ratio (figure 2), in terms of dry mass. Figures for fresh mass followed the same pattern as dry mass. Also the figure for stem length followed the same pattern as stem dry mass; on day 145 the stems of seedlings treated with $1 / 2$ strength solution was about $33 \mathrm{~cm}$, for the $1 / 10$ solution was $10 \mathrm{~cm}$ and for the control treatment the value was around $7 \mathrm{~cm}$.

Table 2 shows the mean relative growth rates $(\overline{\mathrm{R}})$ between days 31 and 108. Only the 1/10 strength solution increased the value of $\bar{R}$ of the root. Stems and leaves showed higher $\overline{\mathrm{R}}$ on the treatment with $1 / 2$ strength and normal strength solutions. Finally, in the case of the seedlings, increasing the strength of the solution increased the values of $\bar{R}$.

Leaf number, area of each leaf and total leaf area were not affected by the $1 / 10$ strength solution, but increasing the concentration of the solution increasead these parameters (figure 3 ). The net assimilation rate $(\overline{\mathrm{E}})$ was higher when the plants did not receive any extra nutrient or received the lowest strength of nutrient solution (table 2). In all treatments, specific leaf area (SLA), leaf weight ratio (LWR) and leaf area ratio (LAR) dropped with age (figure 4). The nutrient solution did not affect SLA. LAR and LWR were higher in plants treated with the higher concentrations of nutrient solution.

By day 145, in terms of fresh mass, the level of total soluble sugars in the roots was reduced in the treatment with higher nutrient concentration (figure 5A) and the level of starch was also reduced when nutrients were added (figure 5C). In tops, there was an increase on total soluble sugars from the first to the third harvest in all treatments (figure 5B); increasing the strength of the solution decreased the content of total soluble sugars on day 145; the higher concentrated nutrient solutions decreased the level of starch compared to water and the 1/10 strength solution treatments. Both in roots and tops the content of nitrogen was higher when the higher concentrated solutions were used (figure 6).

The total carbohydrate/total protein ratio for roots and tops is presented in table 3 , where it can be seen that this ratio is higher for treatments with less or no nutrient addition, and also that the ratio is always higher for the roots than for the tops. Thus, in the partitioning between roots and tops, carbohydrates go preferentially to the roots, and proteins to the tops. This is confirmed by the root/top ratio in terms of carbohydrate or in terms of protein (table 4).

\section{Discussion}

As shown in table 1, the cerrado soil used as substratum is nutritionally very poor $(\mathrm{V}=8 \%)$, with low CEC. In this experiment, nutrient solution was added to this soil, but it is worth remembering that because of the chemical properties of the substratum used in this work it is possible that the nutrients from the Hoagland's solution were not fully available to the plants, even though the addition of nutrients was effective upon growth of D. miscolobium.

The addition of nutrient solution in the cerrado soil used in this work does not seem to modify the $\mathrm{pH}$, as demonstrated by Aveiro (1997) in an experiment using the same soil; she observed acidity index (A.I.) of 4.2 and 4.4 respectively before and

Table 2. Effect of addition of nutrient solution on mean relative growth rate $(\overline{\mathrm{R}})$ and net assimilation rate $(\overline{\mathrm{E}})$, between days 31 and 108 , of $D$. miscolobium seedlings. Small letters compare values in each column.

\begin{tabular}{|c|c|c|c|c|c|}
\hline \multirow{2}{*}{ Treatments } & \multirow[b]{2}{*}{ Root } & \multicolumn{3}{|c|}{$\overline{\mathrm{R}}\left(\mathrm{mg} \cdot \mathrm{mg}^{-1} \cdot \mathrm{day}^{-1}\right)$} & \multirow{2}{*}{$\overline{\mathrm{E}}\left(\mathrm{mg} \cdot \mathrm{cm}^{-2} \cdot\right.$ day $\left.^{-1}\right)$} \\
\hline & & Stem & Leaves & Seedling & \\
\hline Distilled water & $0.042 \mathrm{a}$ & $0.018 \mathrm{a}$ & $0.022 \mathrm{a}$ & $0.031 \mathrm{a}$ & $0.36 \mathrm{a}$ \\
\hline $1 / 10$ strength nutrient solution & $0.048 \mathrm{~b}$ & $0.021 \mathrm{a}$ & $0.024 \mathrm{a}$ & $0.035 \mathrm{~b}$ & $0.46 \mathrm{~b}$ \\
\hline $1 / 2$ strength nutrient solution & $0.040 \mathrm{a}$ & $0.030 \mathrm{~b}$ & $0.033 \mathrm{~b}$ & $0.038 \mathrm{c}$ & $0.25 \mathrm{c}$ \\
\hline Normal strength nutrient solution & $0.040 \mathrm{a}$ & $0.033 \mathrm{~b}$ & $0.036 \mathrm{~b}$ & $0.040 \mathrm{~d}$ & $0.28 \mathrm{c}$ \\
\hline
\end{tabular}



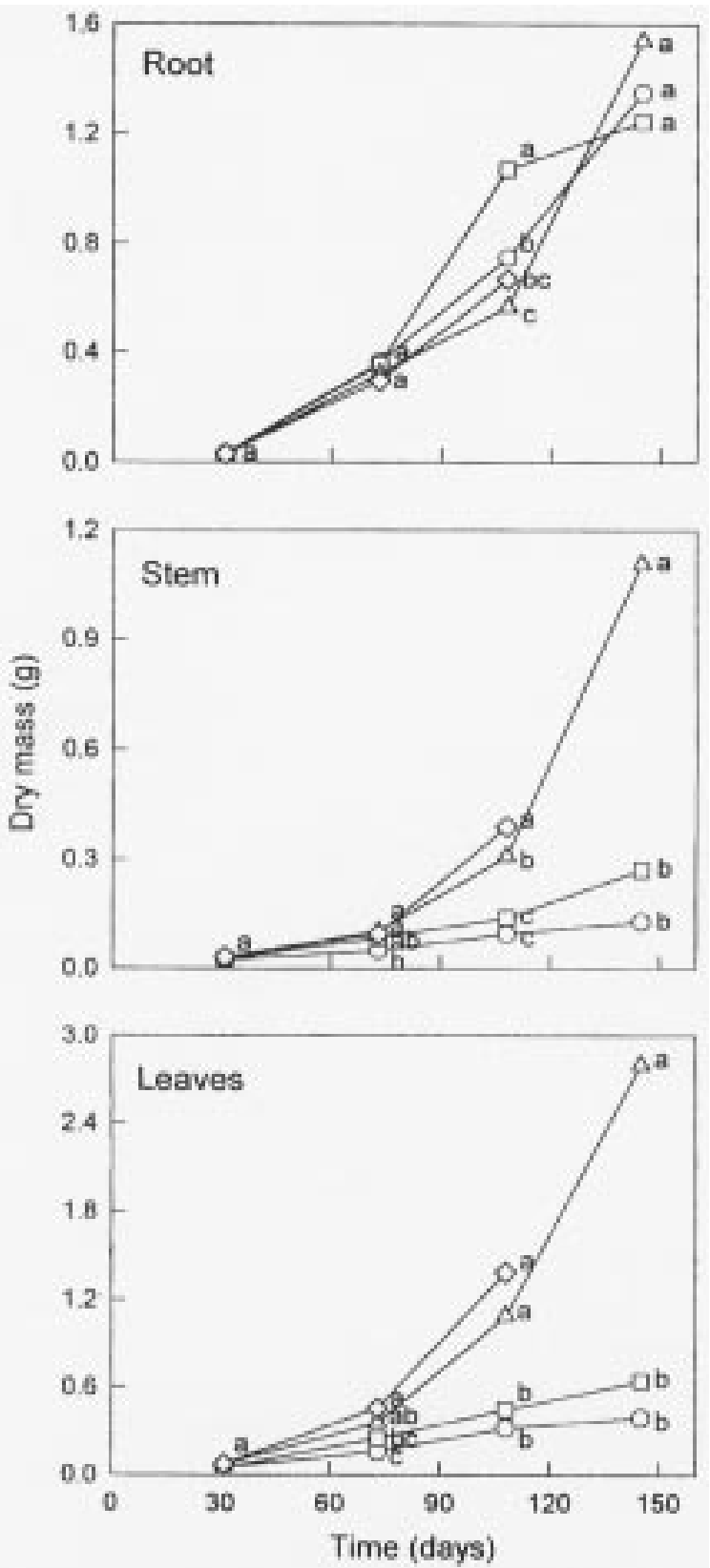

Figure 1. Effect of addition of nutrient solution on dry mass of $D$. miscolobium seedlings growing in cerrado soil. Treatments: distilied water (O), 1/10 strength nutrient solution ( $\square$ ), 1/2 strength nutrient solution $(\Delta)$, normal strength nutrient solution $(\diamond)$. Small letters compare the values in each harvest.

after nutrient solution addition and values of the potential acidity $\left(\mathrm{H}^{+}+\mathrm{Al}^{3+}\right)$ of 2.3 in both cases. So, the results obtained in this work would not be a consequence of $\mathrm{pH}$ alteration.
The promotion of growth by the addition of nutrients became significant only from the second month after planting out seedlings. This confirms the findings of Sassaki \& Felippe (1992a) that no effect of addition of nutrient solution could be seen very early on growth when the seedlings were dependent upon the reserves from the cotyledons. In Qualea grandiflora, the leaf-like photosynthesising cotyledons were responsible for growth of the seedling during a few weeks before the appearance of the first pair of leaves (Paulilo \& Felippe 1994). Other papers dealing with trees from the cerrado have also shown increased growth with the addition of nutrients as in Kielmeyera coriacea (Self 1989) and Qualea grandiflora (Paulilo \& Felippe 1995).

The promotive effect of adding nutrients to cerrado soil in seedlings of $D$. miscolobium was more apparent on the tops than on the roots. This could be seen in the root/top ratio where the values decreased with the increasing strength of the nutrient solution. Normally the root/top ratio is high when a nutrient is missing (Wilson 1988), but a few tree species like Pinus sp. and Acer rubrum were indifferent to increasing the level of nutrients on the substratum, when six nitrogen levels were tested: 10, 25, 50, 100, 200 and 400 ppm (Vaitkus et al. 1993). This shows that the response to the level of nutrients in the substratum is variable. Seedlings of Quercus nigra,

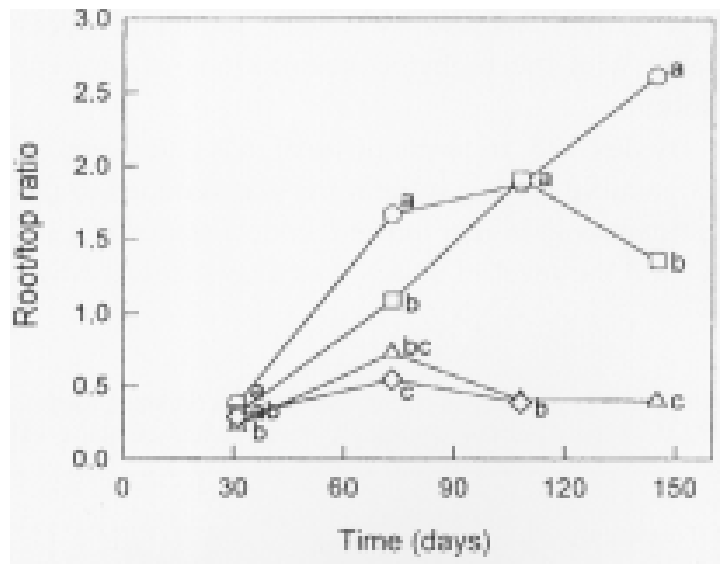

Figure 2. Effect of addition of nutrient solution on the root/top ratio, in terms of dry mass, of $D$. miscolobium seedlings growing in cerrado soil. Treatments: distilled water $(O), 1 / 10$ strength nutrient solution $(\square), 1 / 2$ strength nutrient solution $(\Delta)$, normal strength nutrient solution $(\diamond)$. Small letters compare the values in each harvest. 

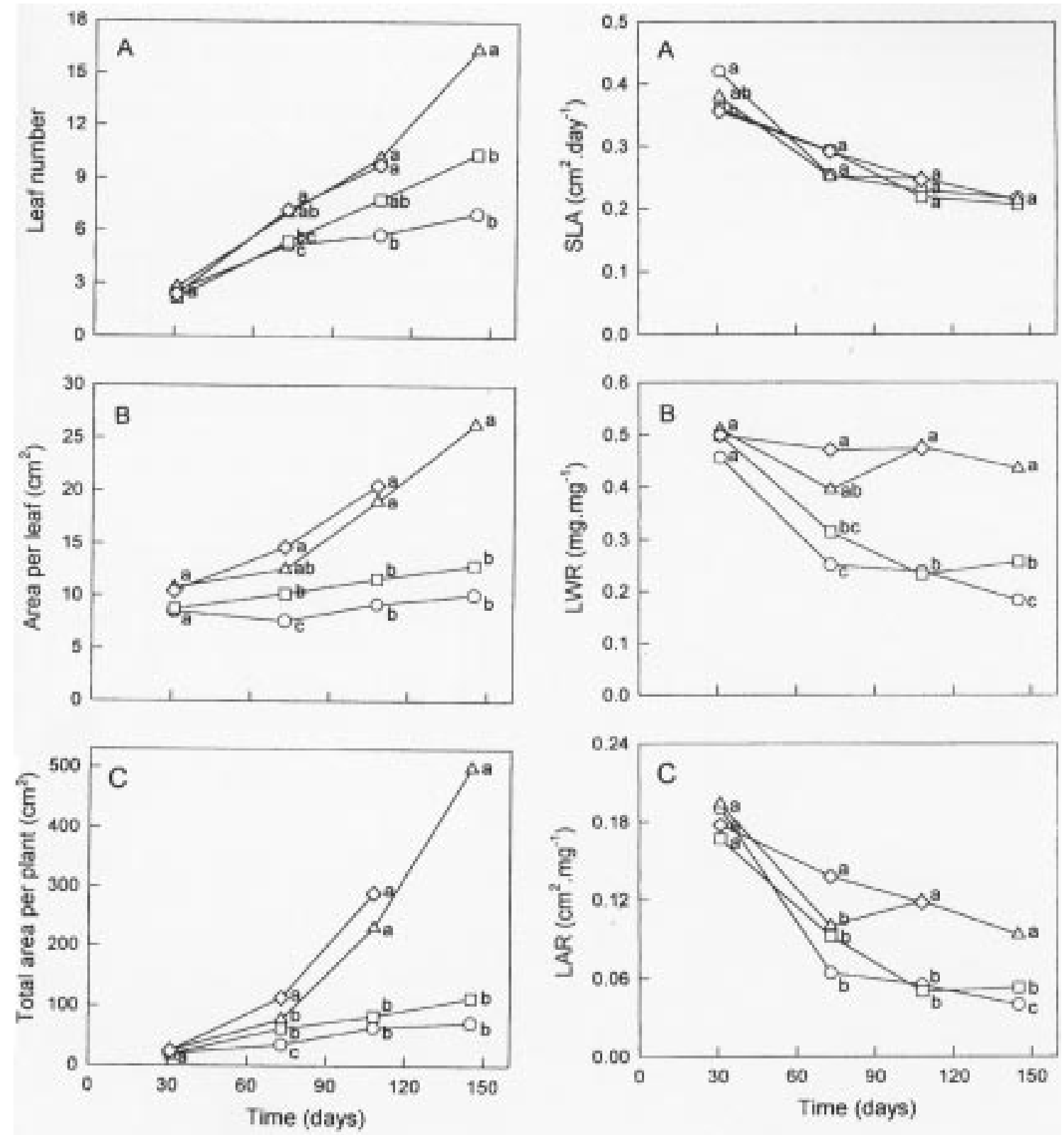

Figure 3. Effect of addition of nutrient solution on leaf growth of D. miscolobium seedlings growing in cerrado soil. A: number of leaves; B: mean area of cach leaf, C: total leaf area. Treatments:distilled water $(O), 1 / 10$ strength nutrient solution $(\square)$, $1 / 2$ strength nutrient solution $(\Delta)$, normal strength nutrient solution $(\diamond)$. Small letters compare the values in cach harvest.

Acer rubrum (Vaitkus et al. 1993), Nauclea diderrichii, Entandrophragama angolense (Riddoch et al. 1991) and Qualea grandiflora (Paulilo et al.

Figure 4. Effect of addition of nutrient solution on SLA (A),LWR (B) and LAR (C) of D. miscolobium seedlings growing in cerrado soil.Treatments:distilled water $(O), 1 / 10$ strength nutrient solution $(\square), 1 / 2$ strength nutrient solution $(\Delta)$, normal strength nutrient solution $(\diamond)$. Small letters compare the values in each harvest.

1994) increased the photosynthetic rate with higher levels of nutrients in the substratum; it was observed a decrease in the case of Carpinus (Vaitkus et al. 1993). 
Table 3. Effect of addition of nutrient solution on carbohydrate/ nitrogen ratio of $D$. miscolobium seedlings.

\begin{tabular}{|c|c|c|c|}
\hline \multirow[b]{2}{*}{ Treatments } & \multicolumn{3}{|c|}{ Carbohydrate / protein ratio } \\
\hline & 73 days & 108 days & 145 days \\
\hline \multirow{6}{*}{$\begin{array}{l}\text { Distilled water } \\
1 / 10 \text { strength nutrient solution } \\
1 / 2 \text { strength nutrient solution } \\
\text { Normal strength nutrient } \\
\text { solution }\end{array}$} & \multicolumn{3}{|c|}{ Root } \\
\hline & 3.0 & 5.6 & 2.0 \\
\hline & 1.2 & 2.6 & 2.1 \\
\hline & 1.3 & 1.4 & 0.8 \\
\hline & 0.7 & 1.1 & - \\
\hline & \multicolumn{3}{|c|}{ Top } \\
\hline Distilled water & 0.6 & 0.5 & 0.4 \\
\hline $1 / 10$ strength nutrient solution & 0.7 & 0.5 & 0.4 \\
\hline $1 / 2$ strength nutrient solution & 0.4 & 0.3 & 0.2 \\
\hline $\begin{array}{l}\text { Normal strength nutrient } \\
\text { solution }\end{array}$ & 0.3 & 0.2 & - \\
\hline
\end{tabular}

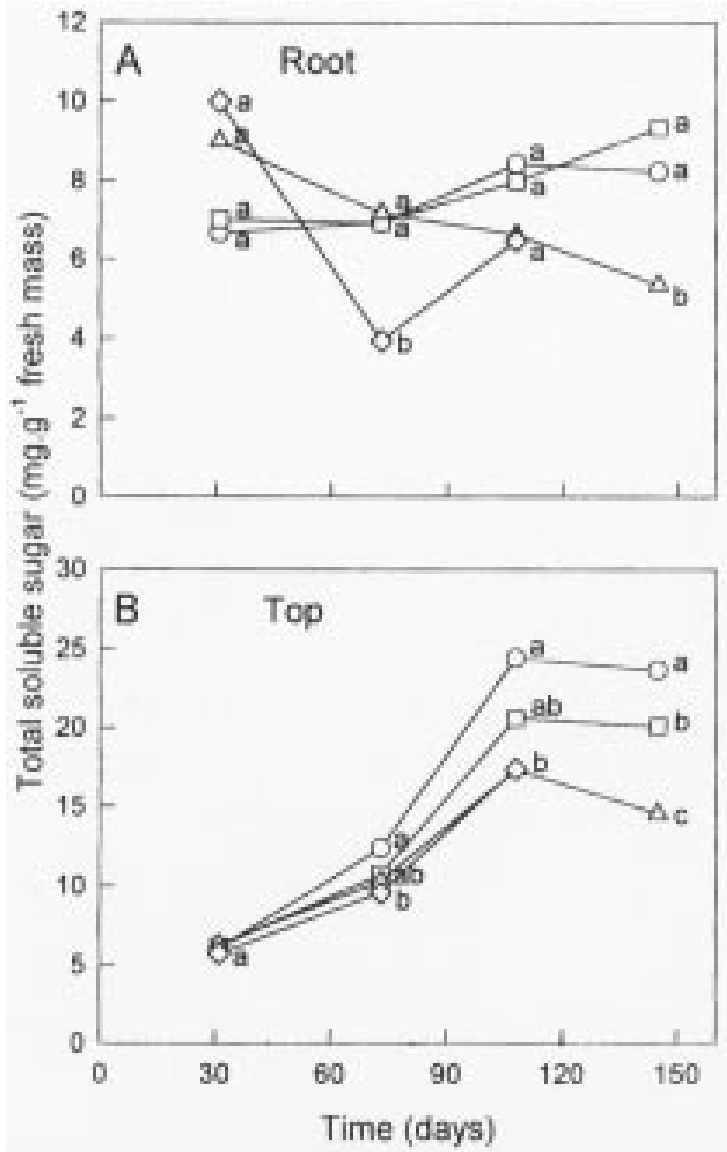

In D. miscolobium there was a higher allocation of carbon to the roots when the nutrient level was low as has been shown also for Glicine max growing in nitrogen defficient substratum (Rufty et al. 1984), and also higher allocation of nitrogen to the tops. Lack of nitrogen will result in a reduction of leaf area and promotion of root growth with an accumulation of soluble sugars in the roots; this will make possible the rapid absorption of nitrogen when it becomes available (Henry \& Raper 1991). No evidence of this adaptation has been shown for cerrado plants, but it would be an adequate mechanism for D. miscolobium plants growing in poor soils.

Paulilo \& Felippe (1994) have suggested that in Qualea grandiflora the increased carbohydrate content, when there is lack of nutrients, could cause a change in metabolism with a poor use of the

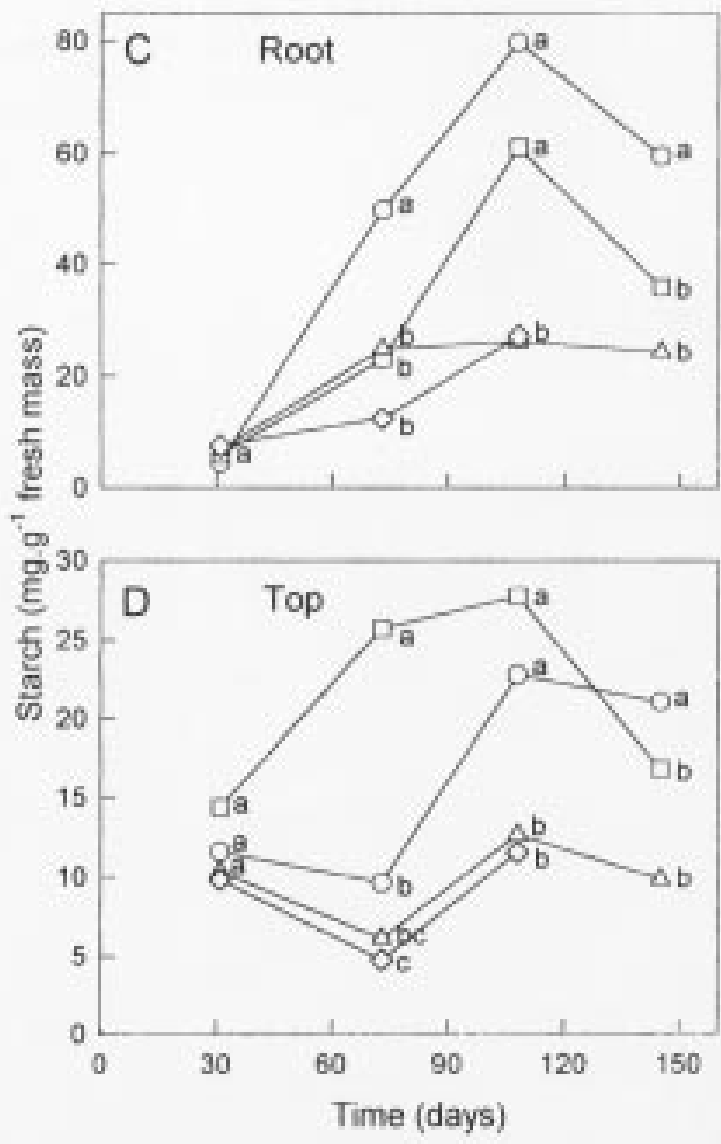

Figure 5. Effect of addition of nutrient solution on total soluble sugars (A, B) and starch content (C, D) in D. miscolobium seedlings growing in cerrado soil. Treatments: distilled water $(O), 1 / 10$ strength nutrient solution $(\square), 1 / 2$ strength nutrient solution $(\Delta)$, normal strength nutrient solution $(\diamond)$. Small letters compare the values in cach harvest. 


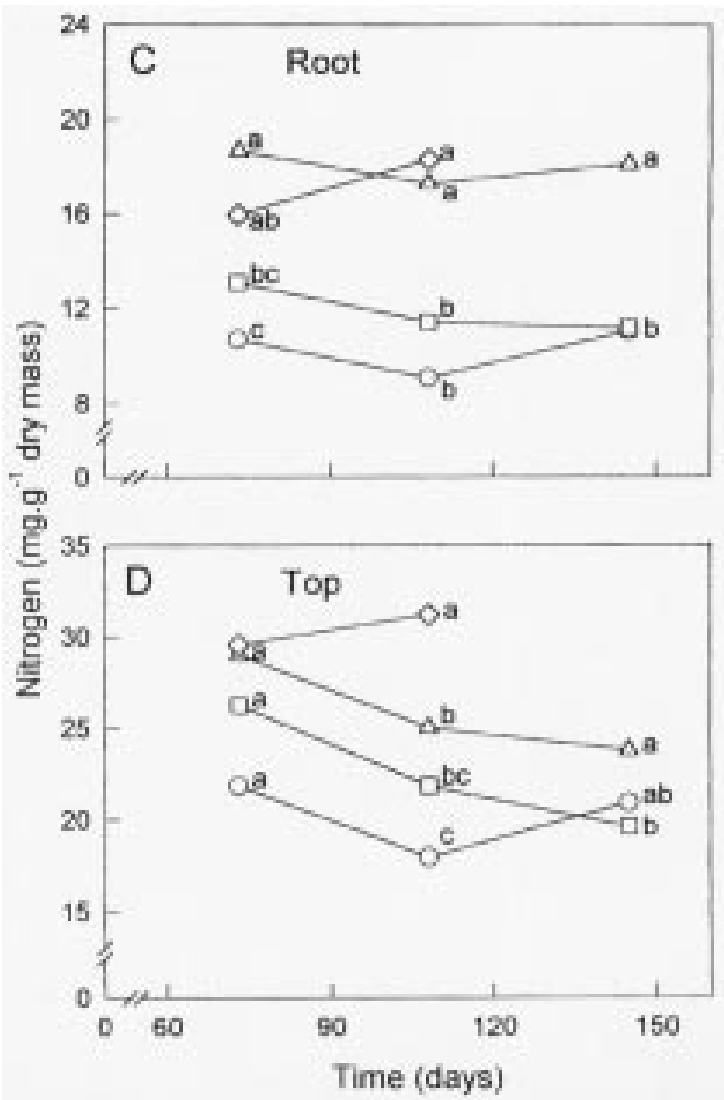

Figure 6. Effect of addition of nutrient solution on nitrogen content in D. miscolobium seedlings growing in cerrado soil. Treatments: distilled water $(O), 1 / 10$ strength nutrient solution $(\square), 1 / 2$ strength nutrient solution $(\Delta)$, normal strength nutrient solution $(\diamond)$. Small letters compare the values in each harvest.

products from photosynthesis and as a consequence a very slow growth. This could also be the case in $D$. miscolobium with an economy of sugars and a reduction of growth. In nutrient deficient soils, the plants may allocate more biomass to survival mechanisms than to growth, thus keeping more reserve material in their tissues (Chapin 1991). According to Chapin (1991) nitrogen deficiency increases the concentration of abscisic acid. This high level of ABA will reduce wall extensibility and thus leaf growth, water conductance from the roots, and turgor. Growth will be inhibited and the use of carbon will be reduced. As a result, an accumulation of carbohydrates will occur and this will reduce photosynthesis. Low nitrogen will also be reflected in low concentration or low activity of some photosynthetic enzymes, like ribulose bisphosphate carboxylase/oxygenase (Gezelius 1986) or low chlorophyll content (Liu \& Dickmann 1992); all this will reduce photosynthesis and growth as a consequence. It must be remembered as well that lack of nitrogen even with optimum supply of water will cause a reduction of turgor of expanding leaves and thus reducing growth (Radin \& Boyer 1982).

According to Beadle (1986), the relative growth rate $(\bar{R})$ is a function of the efficiency of the plant to engage in photosynthesis (to produce dry matter) and of the efficiency to produce assimilatory area; the first one can be analysed by the net assimilation rate $(\overline{\mathrm{E}})$ and the second by LAR (leaf area ratio). This is only true if $\bar{R}$, is instantaneous. However, some suggestion can be made for D. miscolobium, based on this relationship. The slow growth of D.miscolobium seedlings when the nutritional status was poor does not seem to be related to low photosynthetic rate as the values of $\bar{E}$ are higher when no nutrients were added; the same was true when the mean photosynthetic rate was estimated.

It seems that the nutritional status of the soil used in this study does not affect the leaf thickness in $D$. miscolobium since the specific leaf area (SLA) was similar independent of the treatment (with or without addition of nutrients). However increased nutrient supply leads to a higher production of leaves with larger leaflets and thus increased total leaf area (increased LAR). This suggests that mineral deficiency will inhibit emergence of new leaves. Thus the slow growth of this species when there is low

Table 4. Effect of addition of nutrient solution on root/top ratio in terms of carbohydrate and nitrogen contens of D.miscolobium seedlings.

\begin{tabular}{|c|c|c|c|}
\hline \multirow[b]{2}{*}{ Treatments } & \multicolumn{3}{|c|}{ Root / top ratio } \\
\hline & 73 days & 108 days & 145 days \\
\hline \multirow{6}{*}{$\begin{array}{l}\text { Distilled water } \\
1 / 10 \text { strength nutrient solution } \\
1 / 2 \text { strength nutrient solution } \\
\text { Normal strength nutrient } \\
\text { solution }\end{array}$} & \multicolumn{3}{|c|}{ Carbohydrate } \\
\hline & 4.0 & 10.1 & 8.1 \\
\hline & 1.1 & 4.6 & 4.0 \\
\hline & 1.4 & 1.5 & 0.9 \\
\hline & 0.8 & 1.4 & - \\
\hline & \multicolumn{3}{|c|}{ Nitrogen } \\
\hline Distilled water & 0.8 & 1.0 & 1.4 \\
\hline $1 / 10$ strength nutrient solution & 0.7 & 0.9 & 0.8 \\
\hline $1 / 2$ strength nutrient solution & 0.4 & 0.3 & 0.3 \\
\hline $\begin{array}{l}\text { Normal strength nutrient } \\
\text { solution }\end{array}$ & 0.4 & 0.2 & - \\
\hline
\end{tabular}


nutrient supply could be a result of the low capacity for the production of photosynthetic area (LAR) and not a result of lower capacity for photosynthesis (net assimilation rate).

In this work the plants had to be removed from the soil to make the measurements and this complicates the statistical analyses of the derived data (growth analysis parameters). No method is as yet totally acceptable. According to Poorter \& Lewis (1986) any type of analysis will be subjected to error. Thus the results of this work were analysed taking into account only variation of data on the last harvest (time $\mathrm{t}_{2}$ ) and using the mean value for $\mathrm{t}_{1}$.

The death of $D$. miscolobium plants given the higher strength nutrient solution over long periods of time, as seen in this work, was also observed with Qualea grandiflora by Felippe \& Dale (1990). Why this occurs is still unclear.

Acknowledgements - This research was supported by Intenational Scientific Cooperation, EC-Brazil (CI1/0620) and Conselho Nacional de Desenvolvimento Científico e Tecnológico (CNPq, Brazil)

\section{References}

ALVIM, P.T., SANTANA, C.J. \& MIRANDA, E.R. 1968. Avaliação da fertilidade em alguns solos de cerrado em Brasília por meio de ensaios de microparcelas. Ciênc. Cult. 20:613-619.

ARENS, K. 1958a. Considerações sobre as causas do xeromorfismo foliar. Bol. Fac. Fil. Ciênc. Let. Univ. S. Paulo 15:25-26.

ARENS, K. 1958b. O cerrado como vegetação oligotrófica. Boi. Fac. Fil. Ciênc. Let. Univ. S. Paulo 15:59-77.

ARENS, K. 1963. As plantas lenhosas dos campos cerrados como flora adaptada às deficiências minerais do solo. In Simpósio sobre o cerrado (M.G. Ferri, ed.). Editora Edgard Blucher and EDUSP, São Paulo, p.249-265.

AVEIRO, S.M. de G. 1997. Biologia da reprodução e crescimento inicial de Qualea cordata Spreng. (Vochysiaceae), uma espécie arbórea dos cerrados. Tese de doutorado, Universidade Estadual de Campinas, Campinas.

BEADLE, C.L. 1986. Plant growth analysis. In Techniques in bioproductivity and photosynthesis (J. Coombs \& D.O. Hall, eds.). Pergamon Press, Oxford, p.20-25.

CHAPIN F.S., 1980. The mineral nutrition of the wild plants.Annu. Rev. Ecol. Syst. 11:233-260.

CHAPIN F.S., 1991. Integrated responses of plants to stress: a centralized system of physiological responses. Bioscience 41:29-36.

FELIPPE, G.M. \& DALE, J. 1990. The effects of the phosphate supply on growth of plants from the Brazilian cerrado: experiments with seedlings of the annual weed, Bidens gaidneri Baker (Compositae) and the tree, Qualea grandiflora Mart. (Vochysiaceae). Oecologia 82:81-86.

GEZELIUS, K. 1986. Ribulose bisphosphate carboxilase, protein and nitrogen in Scots pine seedlings cultivated at different nutrient level. Physiol. Plant. 68:245-251.
GODOY-AVEIRO, S.M. \& FELIPPE, G.M. 1992. Efeito da remoção de cotilédones no desenvolvimento inicial de Qualea cordata. Hoehnea 19:19-30.

HENRY, L.T. \& RAPER, D. Jr. 1991. Soluble carbohydrate allocalion to roots, photosynthetic rate of leaves, and nitrate assimilation as affected by nitrogen stress and irradiance. Bot. Gaz. 152:23-33.

HOAGLAND, D.R. \& ARNON, D.I. 1938. The water culture method for growing plants without soil. Univ. Calif. Agric. Exper. St. Circ., 347.

HUNT, R. 1982. Plant growth curves: the functional approach to plant growth analysis. Edward Arnold Ltd, London.

LIU, Z. \& DICKMANN, D.I. 1992. Responses of two hybrid Populus clones to flooding, drought, and nitrogen availability. I. Morphology and growth. Can. J. Bot. 70:22652270

McCREADY, R.M., GUGGOLZ, J. SILVIEIRA, V. \& OWENS, H.S. 1950. Determination of starch and amylose in vegetable. Anal. Chem. 22:1156-1158.

MOONEY, H.A. 1972. The carbon balance of plants. Annu. Rev. Ecol. Syst. 3:315-346.

PAULILO, M.T.S. \& FELIPPE, G.M. 1994. Contribuição dos cotilédones e partição de matéria durante o crescimento inicial de Qualea grandiflora Mart.(Vochysiaceae). Revta brasil. Bot. 17:87-91.

PAULILO, M.T.S. \& FELIPPE, G.M. 1995. Resposta de plântulas de Qualea grandiflora, uma espécie arbórea de cerrado, à adição de nutrientes minerais. Revta brasil. Bot. 18:109-112.

PAULILO, M.T.S., FELIPPE, G.M. \& DALE, J. 1994. Crescimento inicial de Qualea gradiflora. Revta brasil. Bot.16:37-46.

POORTER, H. \& LEWIS, C. 1986. Testing differences in relative growth rate: a method avoiding curve fitting and pairing. Physiol. Plant. 67:223-226.

RADIN, J.W. \& BOYER, J.S. 1982. Control of leaf expansion by nitrogen nutrition in sunflower plants: role of hydraulic conductivity and turgor. Plant Physiol. 69:771-775.

RIDDOCH, I., LEHTO, T. \& GRACE, J. 1991. Photosynthesis of tropical tree seedlings in relation to light and nutrient supply. New Phytol. 119:137-147.

RUFTY, T.W. Jr, RAPER, C.D. \& HUBER, S.C. 1984. Alterations in internal partitioning of carbon in soybean plants in response to nitrogen stress. Can. J. Bot. 62:501-508.

SASSAKI, R.M. \& FELIPPE, G.M. 1992a. Remoção dos cotilédones e desenvolvimento inicial de Dalbergia miscolobium. Revta brasil. Bot. 15:1-3.

SASSAKI, R.M. \& FELIPPE, G.M. 1992b. Desenvolvimento inicial de Dalbergia miscolobium em casa de vegetação e em cerrado. Hoehnea 19:75-83.

SELF, G.K. 1989. Studies of xylopodium formation and early seedling growth in Kielmeyera coriacea Mart. PhD thesis, University of Edinburgh, Edinburgh.

SHANNON, J.C. 1968. A procedure for the extraction and fractionation of carbohydrates from immature Zea mays kernels. Res. Bull. 842:1-8.

SNEDECOR, G.W. 1962. Statistical Methods. The Iowa University Press, Iowa.

UMBREIT, W.W., BURIS, R.H., \& STAUFFER, J.E. 1957. Manometric techniques. Burgess Publishing Co., New York.

VAITKUS, M.R., CIRAVOLO, T.G., McLEOD, K.W, MAVITY, E.M. \& NOVAK, K. 1993. Growth and photosynthesis of scedlings of five bottomland tree species following nutrient enrichment. Am. Mid. Nat. 129:42-51.

WILSON, J.B. 1988. A review of evidence on the control of shoot/ root ratio in relation to models. Ann. Bot. 61:433-449. 